\title{
The Effect of Internet Use on Improving Student Learning Outcomes
}

\author{
Moh. Mulyadi Prasetyo ${ }^{1 *}$, Nurhidayah ${ }^{2}$ (D) \\ ${ }^{1}$ Pendidikan Biologi, STKIP Pembangunan Indonesia, Makassary, Indonesia \\ ${ }^{2}$ Pendidikan Biologi, Universitas Muslim Maros, Maros, Indonesia
}

\section{A R T I C L E I N F O}

Article history:

Received September 10, 202

Revised September 11, 2021

Accepted October 12, 2021

Available online November 25, 2021

\section{Kata Kunci:}

Pemanfaatan Internet, media elektronik, Hasil Belajar

\section{Keywords:}

Internet Usage, E-Learning,

Learning Outcomes

DOI:

https://dx.doi.org/10.23887/jet.v5i4 40748

\begin{abstract}
A B S T R A K
Siswa mengalami kesulitan dalam belajar sehingga berdampak pada hasil belajar yang rendah. Rendahnya hasil belajar siswa bisa disebabkan oleh kualitas pembelajaran, salah satunya dari kurangnya sumber referensi belajar. Tujuan dari penelitian ini adalah menganalisis peningkatan hasil belajar Biologi siswa sebelum dan sesudah penerapan pemanfaatan internet. Jenis penelitian ini adalah quasi eksperimen melalui desain Nonequivalent Control Group Design. Subyek pada penelitian ini adalah siswa kelas IX, dimana pada penelitian ini menggunakan dua kelas yaitu kelas kontrol dan kelas eksperimen. Pembelajaran pada kelas kontrol adalah metode ceramah biasa, sedangkan pada kelas eksperimen dilakukan dengan menerapkan metode pemanfaatan internet. Perolehan data hasil belajar menggunakan tes hasil belajar (pretest-posttest). Uji hipótesis menggunakan analisis kovarian bertujuan untuk mengetahui ada tidaknya pengaruh variable bebas terhadap variable terikat. Hasil dari data yang diperoleh menunjukkan bahwa pengaruh pemanfaatan internet dapat meningkatkan hasil belajar siswa. Hasil analisis statistik inferensial diperoleh nilai Sig. hitung 0,000 dengan $\alpha=0,05$ hasil analisis tersebut menunjukkan bahwa nilai Sig.hitung lebih besar dari a $(0,000>0,05)$ sehingga Ho ditolak dan $\mathrm{H}_{1}$ diterima. Jadi dapat disimpulkan bahwa dalam proses pembelajaran dengan memanfaatkan internet sebagai komplemen pembelajaran konvensional dapat meningkatkan hasil belajar siswa. Dengan demikian internet sebagai sumber belajar dapat meningkatkan hasil belajar.
\end{abstract}

\section{A B S T R A C T}

Students have difficulty in learning, so that it has an impact on low learning outcomes. The low student learning outcomes can be caused by the quality of learning, one of which is the lack of learning reference sources. The purpose of this study was analyze improvement of students' Biology learning outcomes before and after the application of internet use. This type of research is a quasi-experimental design through the Nonequivalent Control Group Design. The subjects in this study were students of class IX, which in this study used two classes, namely the control class and the experimental class. Learning in the control class is the usual lecture method, while in the experimental class it is done by applying the method of using the internet. The acquisition of learning outcomes data using the learning outcomes test (pretest-posttest). The hypothesis test using covariance analysis aims to determine whether there is an effect of the independent variable on the dependent variable. The results of the data obtained indicate that the effect of using the internet can improve student learning outcomes. The results of inferential statistical analysis obtained the value of Sig.count 0.000 with $=0.05$. The results of the analysis indicate that the value of Sig.count is greater than $(0.000>0.05)$ so Ho is rejected and H1 is accepted. So it can be concluded that in the learning process by utilizing the internet as a complement to conventional learning can improve student learning outcomes. Thus the internet as a learning resource can improve learning outcomes.

This is an open access article under the CC BY-SA license. Copyright (C) 2021 by Author. Published by Universitas Pendidikan Ganesha.

\section{INTRODUCTION}

The lack of learning activities can be caused by several factors, including the very minimal supply of learning resources such as books and learning media (Asrial et al., 2020; Komikesari et al., 2020; Yusuf \& Widyaningsih, 2020). Even though there are several other media that can be used as a source of learning references, such as using the internet (Binali et al., 2021; Kurniawan \& Rofiah, 2020; Simanihuruk \& Simanungkalit, 2019). However, in its application the internet is still not used in learning. From the author's observation that learning is still teacher-centered. The learning process must be student-centered (Dumitrescu et al., 2014; Yusuf \& Widyaningsih, 2020; Zhang et al., 2020). The teacher is not the only source of learning or information, but acts as a facilitator, evaluator and motivator in learning (Desnita \& Susanti, 2017; Dhiu, 2017; 
Sverdlov et al., 2014). However, in practice, education always faces challenges, especially in terms of quality, relevance, etc. The problem of education quality is one of the challenges in education (Bettencourt et al., 2011; Uygarer \& Uzunboylu, 2017; Zendler \& Greiner, 2020). Educating a large number of children while continuing to maintain a high quality of education is not an easy task, but its quality also needs to be improved from time to time on a regular and continuous (Anuar et al., 2021; Mufit et al., 2020).

Previous research explains The analysis of the low learning outcomes of students (Bunda \& Junaidi, 2021; Ikbal et al., 2019). This is because the learning process is dominated by traditional learning which makes learning ineffective. The classroom environment in this learning is typically teacher-centered, causing students to become passive. In this instance, students are not given learning techniques that allow them to comprehend how to learn from the teacher, think, and motivate themselves (Boyadzhieva, 2016; Fun \& Maskat, 2010). There was a positive and significant influence on the use of the internet as a learning resource on student learning outcomes (Misyanto, 2016). The internet use has a positive influence on student learning outcomes (Azizah et al., 2017). This learning method is based on the development of information technology (IT) through internet technology and has led to what is called e-education or e-learning, namely educational activities or learning through electronic media, primarily through the internet network (Al-Fraihat et al., 2020; Ray, 2018; Villamil et al., 2020). Some of the benefits obtained from using the internet in the learning process include the occurrence of student activities in participating in learning activities which are marked by the number of hits accessing learning sites (Duane \& Satre, 2014; Vrieling et al., 2012). Increasing student motivation in participating in learning (Khan et al., 2021; Yusuf \& Widyaningsih, 2020). Learning activities are characterized by the amount of feedback obtained in the learning process. webmail learning sites. Decreasing the level of student saturation in participating in learning activities (Nácher et al., 2021; Zhang et al., 2020). Increasing students' understanding of learning materials as seen from the quality of test feedback and site learning questions (Ali \& Maksum, 2020; Asrial et al., 2020).

Understanding the internet itself is the largest computer network in the world (Faslah, 2011; Samsudin et al., 2019). A computer network means a group of computers linked together so that users can share information and resources (Liang et al., 2011; Zendler \& Greiner, 2020). The internet, which stands for interconnection networking or also an international network, is a network that connects computers around the world without being limited by the number of units into one network that can access each other (Molly et al., 2017; Tempola et al., 2020). Formative evaluation is a series of teaching and learning processes (Granberg et al., 2021; Hansen, 2020). Formative evaluation will be beneficial if accompanied by the provision of material from books and the internet (Chen \& Chen, 2019; Xiao \& Yang, 2019). This is because the most important thing for students is knowing the value and knowing the extent of the truth of the work they are doing based on the information they get from the internet (Granberg et al., 2021; Schildkamp et al., 2020).

One of the skills that a teacher needs to improve the quality of learning outcomes is knowing computer components, both hardware, and software (Smirnova et al., 2019; Uygarer \& Uzunboylu, 2017). The use of the internet is beneficial and makes it easier for teachers to improve the teaching and learning process and for students to find out how much material has been mastered, thus enabling these students to be motivated to learn to improve their learning outcomes from time to time. from time to time (Hamidah \& Yanuarmawan, 2018; Sert \& Boynueğri, 2017). Field studies prove that from the training provided, every teacher needs to be equipped with knowledge about the skills to identify supporting sites to various learning resources. Utilizing the internet as a learning resource, teachers need to direct students to access certain sites (Rimawati \& Wibowo, 2018). The findings of previous research also stated that the use of the internet could be used as a learning resource (Artati et al., 2016). Other research findings also state that, the use of the internet as a learning resource has a significant effect on learning outcomes (Kurniawan \& Rofiah, 2020; Simanihuruk \& Simanungkalit, 2019). Students need to use the internet as a medium as well as a learning resource in the hope that it can support the learning process in the classroom and expand their knowledge base based on the material provided by the teacher. Based on the problems above, research was conducted on the effect of internet use on the learning outcomes of class XI students in Biology at SMA Negeri 18 Makassar. The purpose of this study is to analyze the improvement of students' Biology learning outcomes before and before the application of the internet.

\section{METHOD}

Quantitative research is the name for this sort of study through quasi-experimental, using the Nonequivalent Control Group Designs. This research was conducted at SMA Negeri 18 Makassar from May to July 2021. The object of this research was all students of class XI IPA SMA Negeri Neg. 18 Makassar consisting of 173 students and divided into five classes with a homogeneous distribution. The sampling technique used in this research is purposive sampling. The sample in this research were 21 students of class IX IPA1 as the control class with details of 5 male students and 16 female students who studied without treatment (conventional method). Furthermore, class IX IPA2 is an experimental class with 29 students with details of the number of 
male students as many as ten and female students as much as eleven who are given learning treatment using the internet method. So the total number of students is 50 students who are divided into two classes. The research instrument used in this study was a pretest-posttest learning outcome test which had previously been tested for the validity and reliability of the instrument. The data in this study were evaluated using descriptive statistical approaches to characterize the distribution of Biology learning outcomes. Find out the value of student learning outcomes based on the scores obtained were analyzed by the formula. Furthermore, for the category of student learning outcomes, the standard categorization technique set by the Ministry of Education and Culture is used as follows Table 1.

Table 1. Categorization of Learning Outcomes

\begin{tabular}{cc}
\hline Kategori & Tingkat penguasaan materi pelajaran \\
\hline Very well & $8,5-10,0$ \\
Well & $6,6-7,9$ \\
Enough & $5,6-6,5$ \\
Not enough & $4,0-5,5$ \\
Fail & $3,0-3,9$ \\
\hline
\end{tabular}

Furthermore, inferential statistical analysis was used to test the proposed research hypotheses. The data obtained from this study were analyzed using analysis of covariance (ANCOVA) with the help of the SPSS (Statistical Product and Service Solution) version 22.0 program.

\section{RESULT AND DISCUSSION}

\section{Result}

The data collected by the author in the research is in the form of student learning outcomes data obtained by using the learning outcomes test instrument given as an ability test to determine student learning outcomes and the level of student material mastery. To find out how the initial ability of class XI IPA1 SMAN 18 Makassar students was first given treatment in the form of a learning outcome test (Pretest). Based on the results of research conducted at SMA Negeri 18 Makassar in class IX IPA1 students, the authors collected data from test instruments through Pre- and post-test learning results of pupils who did not receive internet-based learning treatment. The following is the instrument data for Biology learning outcomes (Pre-test) which were collected before being given an explanation of the learning material in the control group of class XI IPA1 students of SMAN 18 Makassar. The results of the analysis obtained from the Pre-test are the range value (R) 20 , the number of classes is 5.39 , the class interval/class length is 4 , the average $(\mathrm{X})$ is 34.36 , and the variance $\left(\mathrm{S}^{2}\right)$ is 33.42 .

The following is the instrument data for Biology learning outcomes (Post test) for class IX IPA1 students after being given an explanation of the material without providing a method using the internet. The results obtained from the Post test are the range value $(\mathrm{R})$ is 35 , the number of classes is 5.39 , the class interval/class length is 6 , the average $(\mathrm{X})$ is 50.42 , and the variance $\left(\mathrm{S}^{2}\right)$ is 132.32 .Based on the results of research conducted at SMA Negeri 18 Makassar in class IX IPA2 students, the researchers collected data from the test instrument through the Pre- and post-test learning results of pupils who did not receive internet-based learning treatment.The following is the instrument data for Biology learning outcomes (Pretest) which were collected before being given an explanation of the subject matter in the experimental group of class XI IPA1 SMAN 18 students. The results obtained from the Pre-test were the range value (R) was 15, the number of classes was 5,82 , class interval/class length is 2 , mean $(\mathrm{X})$ is 31.26 , and variance $\left(\mathrm{S}^{2}\right)$ is 31.38 . The following is the instrument data for Biology learning outcomes (Post-test) students of class IX IPA2 after being given the method of using the internet. The results obtained from the post-test are range values (R) 20, number of classes 5.82, class interval/class length 3, average $(X) 76.4$, and variance $\left(S^{2}\right)$ 28.6. Student learning outcomes in control and experimental classrooms, both pre- and post-test, are summarized in the following table for comparison purposes.

As illustrated in Tables 1 and 2, the number of experimental students enrolled in the "very good" category are 12 people (58.62\%), who are in the "good" category as many as 17 people $(41.38 \%)$. There are none in the "adequate" category $(0 \%)$, the "less" category, none $(0 \%)$, and the "failure" category does not exist $(0 \%)$. While in the control class there were no students in the "very good" category $(0 \%)$, in the "good" category there were 10 people $(47.62 \%)$, in the "enough" category 11 people $(52.38 \%)$. In the "less" category there is none $(0 \%)$ and the "failure" category also does not exist $(0 \%)$. From these data, it can be concluded that the experimental class students' learning outcomes at the time of the final test (posttest) were significantly greater than those of pupils in the control class. 
Table 2. Comparison of Biology learning Outcomes

\begin{tabular}{lcc}
\hline \multicolumn{1}{c}{ Description } & $\begin{array}{c}\text { Control Class Learning } \\
\text { Outcomes }\end{array}$ & Eksperimental Class Learning Outcomes \\
\hline High score & 75 & 90 \\
Low score & 40 & 70 \\
Average value & 50,42 & 76,4 \\
Varians & 132,32 & 28,6 \\
\hline
\end{tabular}

Table 3. Category of learning outcomes for the experimental class and the control class

\begin{tabular}{cccccc}
\hline \multirow{2}{*}{ Description } & \multirow{2}{*}{ Value iterval } & \multicolumn{3}{c}{ Frequency, percentage and category of learning outcomes } \\
\cline { 3 - 6 } & & \multicolumn{2}{c}{ Eksperiment } & \multicolumn{2}{c}{ Control } \\
\cline { 3 - 6 } & & Frekuensi & \% & Frekuensi & \% \\
\hline Very well & $81-100$ & 17 & 58,62 & - & - \\
Well & $61-80$ & - & 41,38 & 10 & 47,62 \\
Enough & $41-60$ & - & - & 11 & 52,38 \\
Not enough & $21-40$ & - & - & - & - \\
Fail & $0-20$ & $\mathbf{2 9}$ & $\mathbf{1 0 0}$ & $\mathbf{2 1}$ & - \\
\hline Amount & & & &
\end{tabular}

Before testing the hypothesis, a normality test is carried out first, because this is a test requirement in inferential analysis (Sugiyono, 2016). The normality test aims to see whether the data in both groups are normally distributed. Based on the results of the analysis with the help of SPSS (Statistical Product and Service Solution) version 22.0, the Sig.count value for the control class is 0.805 and the Sig.count value for the experimental class is 0.068 , while the value of (2-sided test) is 0.025 . So that Sig.count $>$ or $0.805>0.025$ and $0.068>0.025$, it can be concluded that $\mathrm{H}_{0}$ which states that the population is normally distributed is accepted and $\mathrm{H}_{1}$ which states that the population is not normally distributed is rejected. The homogeneity test aims to see whether the data in the two groups come from a homogeneous population (Novitasari et al., 2019; Sumardi Hr \& Surianti, 2019). Based on the results of the analysis with the help of SPSS (Statistical Product and Service Solution) version 22.0, the value of Sig. count is 0.013 while the value $=0.05$, thus the value of Sig.count $>$ $(0.05)$ or $0.013>0,05$. So it can be concluded that the two groups are homogeneous. Hypothesis testing was conducted to determine whether student learning outcomes in the experimental group differed significantly from student learning outcomes in the control group (Gunawan, 2020; Puspita et al., 2017). For analysis purposes, covariance analysis was used with the help of SPSS (Statistical Product and Service Solution) version 22.0. With the test criteria is if the value of Sig.count $<(0.05)$ then $\mathrm{H}_{1}$ is accepted and $\mathrm{H}_{0}$ is rejected, meaning There is a difference in the learning outcomes of biology students between the experimental and control classes.

\section{Discussion}

The control group learning outcomes data illustrates that the Biology learning system with learning by doing and the flow of dialogic communication between teachers and students in Biology learning must be improved. This is consistent with research findings, regarding the analysis of low student learning outcomes (Enas Almanasreh et al., 2019; Rahayuningsih, 2020; Setiawan \& Ari Oka, 2020). This is because the learning process is dominated by traditional learning (ordinary lecture method) (Arthaningsih \& Diputra, 2018; Handayani et al., 2017; Widiantini et al., 2017). The classroom environment in this learning is typically teachercentered, causing students to become passive. In this instance, students are not given learning techniques that allow them to comprehend how to learn not only from the teacher, think, and motivate themselves. This shows that without applying learning methods will affect the quality of student learning outcomes (Dupri et al., 2020; Marzuki \& Basariah, 2017; Tanti et al., 2021). There are disparities in the learning outcomes of pupils who use the method vs those who use conventional methods (Armiyanti, 2019; Haji et al., 2015). Furthermore, the problem-solving ability of students who were given learning using the method would be higher than the problem-solving abilities of students who were given conventional learning (Parto, 2011; Rosidah et al., 2018).

The experimental group's learning outcomes data show that the application of the internet utilization method can increase the average score of students and is able to increase the number of students who fall into the very high level of completeness category. Additionally, internet-based learning it is hoped that students will get used to thinking critically and encourage students to become self-taught learners (Al-Fraihat et al., 2020; Samsudin et al., 2019). Students will also be accustomed to seeking various information from various sources for learning (Safitri et al., 2019; Tsivitanidou \& Constantinos, 2016). Learning by utilizing the internet as a learning 
resource can establish independence and educate students to work together with other students in small groups or teams (Ferri et al., 2020). One more thing that is no less important is that with internet-based learning students' knowledge and insight can develop, able to improve student learning outcomes, thus the quality of education will also increase (Izza et al., 2019). This corresponds to research, which states that with learning activities through elearning it is possible to develop optimal student learning flexibility, where students can access learning materials at any time and repeatedly (Sugandi et al., 2018; Sugiyanto et al., 2019). This is certainly different from conventional learning, where the learning process of students and teachers has been determined by time and place. The learning outcomes of students who learn to use a method will be better than students who study conventionally (Al-Fraihat et al., 2020; Rahmawati \& Partana, 2019). Research shows that there are disparities in the outcomes of students who learn to apply strategies and those who study conventionally.

Based on the results of the analysis with the help of SPSS (Statistical Product and Service Solution) version 22.0, the Sig.count value is 0.000 with $=0.05$. Thus it is clear that the value of Sig.count $(0.000)<$ $(0.05)$, means that $\mathrm{H}_{0}$ is rejected. So there is a significant difference between student learning outcomes in the control class and the experimental class. Thus it can be said that learning by utilizing the internet is better and can improve student learning outcomes when compared to students who are taught without the application of the method. The internet is very useful as a learning resource (Hamidah \& Yanuarmawan, 2018; Sasmita, 2020). In addition, the use of the internet as a reference source can increase students' independence in completing assignments (Juwandi \& Widyana, 2019). In addition, the research stated that the internet as a learning resource can be used as an alternative in a pandemic situation (Arizona et al., 2020). The designing learning through the internet as a source of information in addition to improving learning outcomes also increases student learning achievement because learning through the internet contains the principles of learning by doing, trial and trying to improve.

\section{CONCLUSION}

The increase in student learning outcomes who are taught using the internet (e-learning) is higher than students who are taught without this method. With the use of the internet (e-learning) method, it is known that there is a significant difference between the learning outcomes of students who are taught using the internet (elearning) and students who do not use the internet (e-learning). The level of mastery of the material taught by applying the internet utilization method (e-learning) is better than the students who are taught without the application of the method.

\section{REFERENCES}

Al-Fraihat, D., Joy, M., Masa'deh, R., \& Sinclair, J. (2020). Evaluating E-learning systems success: An empirical study. Computers in Human Behavior, 102, 67-86. https://doi.org/10.1016/j.chb.2019.08.004.

Ali, M. K., \& Maksum, H. (2020). Utilization of E-Learning-Based ICT Learning Using the Google Classroom Application During the COVID-19 Pandemic. Journal of Education Research and Evaluation, 4(4), 373. https://doi.org/10.23887/jere.v4i4.29181.

Anuar, S., Nizar, N., \& Ismail, M. A. (2021). The Impact of Using Augmented Reality as Teaching Material on Students' Motivation. Asian Journal of Vocational Education And Humanities, 2(1). https://doi.org/10.53797/ajvah.v2i1.1.2021.

Arizona, K., Abidin, Z., \& Rumansyah, R. (2020). Pembelajaran Online Berbasis Proyek Salah Satu Solusi Kegiatan Belajar Mengajar Di Tengah Pandemi Covid-19. Jurnal Ilmiah Profesi Pendidikan, 5(1). https://doi.org/10.29303/jipp.v5i1.111.

Armiyanti, A. (2019). Penerapan Model Pembelajaran Matematika Realistik untuk Meningkatkan Aktivitas dan Hasil Belajar Siswa SD. ANARGYA: Jurnal Ilmiah Pendidikan Matematika, 2(2). https://doi.org/10.24176/anargya.v2i2.3904.

Artati, Y., -, T., \& -, S. (2016). Hubungan Antara Pemanfaatan Internet Sebagai Sumber Belajar Dengan Prestasi Belajar Mahasiswa Semester III Prodi Diii Kebidanan Sutomo Surabaya. SAINTEKBU, 3(1). https://doi.org/10.32764/saintekbu.v3i1.43.

Arthaningsih, N. K. J., \& Diputra, K. S. (2018). Pengaruh Model Pembelajaran Kooperatif Tipe Two Stay Two Stray melalui Lesson Study terhadap Hasil Belajar Matematika. Journal of Education Technology, 2(4), 128-136. https://doi.org/10.23887/jet.v2i4.16424.

Asrial, Syahrial, Maison, Kurniawan, D. A., \& Piyana, S. O. (2020). Ethnoconstructivism E-Module to Improve Perception, Interest, and Motivation of Students in Class V Elementary School. JPI (Jurnal Pendidikan Indonesia), 9(1), 30-41. https://doi.org/10.23887/jpi-undiksha.v9i1.19222.

Azizah, S., Khuzaemah, E., \& Rosdiana, I. (2017). Penggunaan Media Internet eXe-Learning Berbasis Masalah 
pada Materi Perubahan Lingkungan untuk Meningkatkan Hasil Belajar Siswa dalam kehidupan sehariharinya dan juga psikomotor ( keterampilan ) siswa. Proses belajar dapat materi dan bahan belajar yang. Scientiae Educatia: Jurnal Pendidikan Sains, 2005, 197-213. https://doi.org/10.24235/sc.educatia.v6i2.1957.

Bettencourt, C., Velho, J. L., \& Almeida, P. A. (2011). Biology teachers' perceptions about ScienceTechnology-Society (STS) education. Procedia - Social and Behavioral Sciences, 15. https://doi.org/10.1016/j.sbspro.2011.04.262.

Binali, T., Tsai, C.-C., \& Chang, H.-Y. (2021). University students' profiles of online learning and their relation to online metacognitive regulation and internet-specific epistemic justification. Computers \& Education, 175. https://doi.org/10.1016/j.compedu.2021.104315.

Boyadzhieva, E. (2016). Learner-centered Teaching and Learner Autonomy. Procedia - Social and Behavioral Sciences, 232, 35-40. https://doi.org/10.1016/j.sbspro.2016.10.008.

Bunda, A. P., \& Junaidi, J. (2021). Penyebab Rendahnya Hasil Belajar Peserta Didik Kelas X IIS Mata Pelajaran Sosiologi Semester Ganjil Tahun Ajaran 2020/2021 Di SMAN 10 Padang. Jurnal Sikola: Jurnal Kajian Pendidikan Dan Pembelajaran, 2(4). https://doi.org/10.24036/sikola.v2i4.130.

Chen, C.-M., \& Chen, M.-C. (2019). Mobile formative assessment tool based on data mining techniques for supporting web-based learning. Computers \& Education, 5(2). https://doi.org/10.1016/j.compedu.2008.08.005.

Desnita, D., \& Susanti, D. (2017). Science Process Skills-Based Integrated Instructional Materials to Improve Student Competence Physics Education Prepares Learning Plans on Teaching Skills Lectures. Jurnal Penelitian \& Pengembangan Pendidikan Fisika, 3(1), 35. https://doi.org/10.21009/1.03105.

Dhiu, K. D. (2017). Learning Motivation And Perception Of The Teachers' Pedagogic Competence And Learning Achievement In Social Science Of Junior High School Students. Journal of Education Technology, 1(1), 6-12. https://doi.org/10.23887/jet.v1i1.10078.

Duane, B. T., \& Satre, M. E. (2014). Utilizing constructivism learning theory in collaborative testing as a creative strategy to promote essential nursing skills. Nurse Education Today, 34(1). https://doi.org/10.1016/j.nedt.2013.03.005.

Dumitrescu, C., Olteanu, R. L., Gorghiu, L. M., \& Gorghiu, G. (2014). Learning Chemistry in the Frame of Integrated Science Modules - Romanian Student's Perception. Procedia - Social and Behavioral Sciences, 116(September 2015), 2516-2520. https://doi.org/10.1016/j.sbspro.2014.01.603.

Dupri, D., Candra, O., Candra, A., \& Suryani, D. A. (2020). The Implementation of Problem Based Learning Model in Improving Cooperation and Learning Outcomes in Physical Education. Jurnal Pendidikan Jasmani Dan Olahraga, 5(1). https://doi.org/10.17509/jpjo.v5i1.22531.

Enas Almanasreh, E., Moles, R., \& Timothy, M. (2019). Evaluation of methods used for estimating content validity. Research in Social and Administrative Pharmacy, 15(2), 214-221. https://doi.org/10.1016/j.sapharm.2018.03.066.

Faslah, R. (2011). Pemanfaatan Internet Dalam Pengembangan Konsep Ips Dan Implikasinya Terhadap Pembelajaran Bermakna. Econosains Jurnal Online Ekonomi Dan Pendidikan, 9(2), 167-170. https://doi.org/10.21009/econosains.0092.07.

Ferri, F., Grifoni, P., \& Guzzo, T. (2020). Online Learning and Emergency Remote Teaching: Opportunities and Challenges in Emergency Situations. Societies, 10(4), 86. https://doi.org/10.3390/soc10040086.

Fun, C. S., \& Maskat, N. (2010). Teacher-Centered Mind Mapping vs Student-Centered Mind Mapping in the Teaching of Accounting at Pre-U Level - An Action Research. International Conference on Learner Diversity, 240. https://doi.org/10.1016/j.sbspro.2010.10.034.

Granberg, C., Palm, T., \& Palmberg, B. (2021). A case study of a formative assessment practice and the effects on students' self-regulated learning. Studies in Educational Evaluation. https://doi.org/10.1016/j.stueduc.2020.100955.

Gunawan, D. (2020). Pengaruh Media Video Interaktif Terhadap Hasil Belajar Kognitif Kelasa Iv Sd Negeri 2 Karangrejo Trenggalek. Eduproxima: Jurnal Ilmiah Pendidikan IPA, 2(1). https://doi.org/10.29100/eduproxima.v2i1.1489.

Haji, A. G., Safriana, \& Safitri, R. (2015). The use of problem based learning to increase students' learning independent and to investigate students' concept understanding on rotational dynamic at students of SMA Negeri 4 Banda Aceh. Jurnal Pendidikan IPA Indonesia, 4(1), 67-72. https://doi.org/10.15294/jpii.v4i1.3503.

Hamidah, F. N., \& Yanuarmawan, D. (2018). Pemanfaatan Internet Untuk Memvariasikan Sumber Belajar Bahasa Inggris dalam Meningkatkan Kinerja Guru. Jurnal ABDINUS : Jurnal Pengabdian Nusantara, 2(1). https://doi.org/10.29407/ja.v2i1.11790.

Handayani, N. M. D., Ganing, N. N., \& Suniasih, N. W. (2017). Model Pembelajaran Picture and Picture Berbantuan Media Audio-Visual Terhadap Pengetahuan IPA. Journal of Education Technology, 1(3), 
176. https://doi.org/10.23887/jet.v1i3.12502.

Hansen, G. (2020). Formative assessment as a collaborative act. Teachers`Intention and Students`Experience: Studies in Educational Evaluation, 66. https://doi.org/10.1016/j.stueduc.2020.100904.

Ikbal, I., Taena, L., \& Ilham, M. (2019). Faktor Penyebab Rendahnya Hasil Belajar Siswa Kelas XI Pada Mata Pelajaran Ekonomi Di SMA Negeri 1 Bone Kabupaten Muna. Jurnal Online Program Studi Pendidikan Ekonomi, 4(1). https://doi.org/10.36709/jopspe.v4i1.13526.

Izza, S., Ningrum, B. S., \& Hariyati, R. T. S. (2019). Pemanfaatan Webinar dalam Bidang Keperawatan. Jurnal Penelitian Perawat Profesional, 1(1). https://doi.org/10.37287/jppp.v1i1.14.

Juwandi, J., \& Widyana, R. (2019). Pengaruh kemandirian belajar terhadap pemanfaatan internet sebagai sumber belajar. JURNAL SPIRITS, 10(1). https://doi.org/10.30738/spirits.v10i1.6536.

Khan, M. A., Vivek, Nabi, M. K., Khojah, M., \& Tahir, M. (2021). Students' Perception towards E-Learning During Covid-19 Pandemic In India: An Empirical Study. Sustainability, 13(1). https://doi.org/10.3390/su13010057.

Komikesari, H., Mutoharoh, M., Dewi, P. S., Utami, G. N., Anggraini, W., \& Himmah, E. F. (2020). Development of e-module using flip pdf professional on temperature and heat material. Journal of Physics: Conference Series, 1572(1). https://doi.org/10.1088/1742-6596/1572/1/012017.

Kurniawan, M. R., \& Rofiah, N. H. (2020). Pola Penggunaan Internet di Lingkungan Sekolah Dasar Se-Kota Yogyakarta. Southeast Asian Journal of Islamic Education, 2(2). https://doi.org/10.21093/sajie.v2i2.1930.

Liang, Y., Zheng, T., \& Wang, M. (2011). English audio-visual teaching mode and its teaching environment construction - Henan Institute of Science and Technology as the example. 2011 International Conference on Multimedia Technology, 3050-3053. https://doi.org/10.1109/ICMT.2011.6001924.

Marzuki, \& Basariah. (2017). The Influence Of Problem-Based Learning And Project Citizen Model In The Civic Education Learning On Student'scritical Thinking Ability And Self Discipline. Cakrawala Pendidikan, 6(3), 382-400. https://journal.uny.ac.id/index.php/cp/article/view/14675/pdf.

Misyanto, M. (2016). Analisis Faktor Penyebab Rendahnya Hasil Belajar Peserta Didik Kelas V Pada Mata Pelajaran Matematika. Anterior Jurnal, 15(2), 144-150. https://doi.org/10.33084/anterior.v15i2.49.

Molly, B., Tanaamah, A. R., \& Sitokdana, M. N. N. (2017). Analisis Kinerja Sistem Informasi dan Teknologi Informasi untuk Menunjang Kinerja Karyawan Menggunakan Framework IT Balanced Scorecard (Studi Kasus pada Wi-Fi Universitas Kristen Satya Wacana). Jurnal Teknologi Informasi Dan Ilmu Komputer, 4(4). https://doi.org/10.25126/jtiik.201744499.

Mufit, F., Asrizal, Hanum, S. ., \& Fadhilah, A. (2020). Preliminary research in the development of physics teaching materials that integrate new literacy and disaster literacy Preliminary research in the development of physics teaching materials that integrate new literacy and disaster literacy. The 2nd International Conference on Research and Learning of Physics, 0-12. https://doi.org/10.1088/17426596/1481/1/012041.

Nácher, M. J., Badenes-Ribera, L., Torrijos, C., \& Ballesteros, M. A. (2021). The effectiveness of the GoKoan elearning platform in improving university students' academic performance. Studies in Educational Evaluation, 70. https://doi.org/10.1016/j.stueduc.2021.101026.

Novitasari, A., Eka, K. I., \& Bramasta, D. (2019). Pengaruhcontextual Teaching And Learningterhadap Motivasi Belajar Dan Keterampilan Berpikir Kritis. Jurnal Dikdas Bantara, 2(2). https://doi.org/10.32585/jdb.v2i2.373.

Parto, M. (2011). Problem solving, self- efficacy, and mental health in adolescents: Assessing the mediating role of assertiveness. Procedia - Social and Behavioral Sciences, 30. https://doi.org/10.1016/j.sbspro.2011.10.125.

Puspita, L., Yetri, Y., \& Novianti, R. (2017). Pengaruh Model Pembelajaran Reciprocal Teaching Dengan Teknik Mind Mapping Terhadap Kemampuan Metakognisi Dan Afektif Pada Konsep Sistem Sirkulasi Kelas Xi Ipa Di Sma Negeri 15 Bandar Lampung. Biosfer: Jurnal Tadris Biologi, 8(1). https://doi.org/10.24042/biosf.v8i1.1265.

Rahayuningsih, S. (2020). Animation media of animal husbandry thematic science learning to stimulate scientific attitude in early childhood. International Journal of Scientific and Technology Research. https://doi.org/10.23887/jet.v3i1.17959 Article Metrics.

Rahmawati, T., \& Partana, C. F. (2019). Pengaruh Media Pembelajaran Asam Basa Berbasis Android Terhadap Efikasi Diri Peserta Didik. JTK (Jurnal Tadris Kimiya), 4(2). https://doi.org/10.15575/jtk.v4i2.5022.

Ray, P. P. (2018). A survey on Internet of Things architectures. In Journal of King Saud University - Computer and Information Sciences (Vol. 30, Issue 3). https://doi.org/10.1016/j.jksuci.2016.10.003.

Rimawati, E., \& Wibowo, A. (2018). Pengaruh Persepsi Guru Sekolah Dasar Terhadap Minat Menggunakan Internet Sebagai Sumber Belajar. Jurnal Sains Dan Informatika, 4(2). https://doi.org/10.34128/jsi.v4i2.134. 
Rosidah, Ketut Budayasa, I., \& Juniati, D. (2018). An Analysis of Statistical Reasoning Process of High School Students in Solving the Statistical Problem. Journal of Physics: Conference Series, 1028(1). https://doi.org/10.1088/1742-6596/1028/1/012125.

Safitri, A., Atmadja, N. B., \& Mudana, I. W. (2019). Penggunaan Internet Sebagai Sumber Belajar Sosiologi Siswa IPS di SMAN 1 Singaraja. E-Jornal Pendidikan Sosiologi Universitas Pendidikan Ganesha, 1(3).

Samsudin, A., Kelana, J. B., \& Muftianti, A. (2019). Utilization of Internet-Based Learning Media in Enhancing Science Literacy Capabilities of Pgsd Students. PrimaryEdu - Journal of Primary Education, 3(2), 91. https://doi.org/10.22460/pej.v3i2.1284.

Sasmita, R. S. (2020). Research \& Learning in Primary Education Pemanfaatan Internet Sebagai Sumber Belajar. Jurnal Pendidikan Dan Konseling, 1. https://doi.org/10.21009/PIP.151.3.

Schildkamp, K., Kleij, van der, Heitink, Kippers, W. B., \& Veldkamp, B. P. (2020). Formative assessment: A systematic review of critical teacher prerequisites for classroom practice. International Journal of Educational Research. https://doi.org/10.1016/j.ijer.2020.101602.

Sert, N., \& Boynueğri, E. (2017). Digital technology use by the students and english teachers and self-directed language learning. World Journal on Educational Technology: Current Issues, 9(1), 24. https://doi.org/10.18844/wjet.v9i1.993.

Setiawan, I. M. D., \& Ari Oka, I. D. G. (2020). The Use of Audio-Visual Assisted Google Classroom for Mathematics Course. Journal of Education Technology, 4(3), 244. https://doi.org/10.23887/jet.v4i3.28529.

Simanihuruk, L. A., \& Simanungkalit, N. M. (2019). Pengaruh Penggunaan Internet Sebagai Sumber Belajar Pada Materi Penginderaan Jauh dan Sig Terhadap Hasil Belajar Tengah Semester Geografi Kelas XII IPS SMA Negeri 21 Medan. Tunas Geografi, 7(1). https://doi.org/10.24114/tgeo.v7i1.11087.

Smirnova, Vaganova, Lebedeva, Livshits, \& Kaznacheeva. (2019). Management of Teacher Certification in Educational Institution. International Journal of Innovative Technology and Exploring Engineering, 9(2), 1038-1042. https://doi.org/10.35940/ijitee.k2131.129219.

Sugandi, R. M., Suparno, M., Wena, M., Pribadi, M., \& Ismail, H. (2018). Effect of Activity-Based Learning on Student Learning Achievement in Construction Management. https://doi.org/10.2991/icli-17.2018.40.

Sugiyanto, S., Wena, M., \& Isnandar, I. (2019). Developing Learning Materials Based On Training Within Industry (Twi) To Improve The Building Construction Student's Learning Outcomes. Jurnal Ilmu Pendidikan, 24(2). https://doi.org/10.17977/um048v24i2p80-85.

Sugiyono. (2011). Sugiyono. 2011. Metode Penelitian Kuantitatif, Kualitatif dan R\&D. Bandung: Afabeta. In Bandung:Alfabeta.

Sumardi Hr, \& Surianti. (2019). Pengaruh Pemberdayaan, Kompetensi, Dan Kepuasan Kerja Terhadap Kinerja Dosen Universitas Wiralodra Indramayu. Jurnal Investasi, 5(1). https://doi.org/10.31943/investasi.v5i1.20.

Sverdlov, A., Aram, D., \& Levin, I. (2014). Kindergarten teachers' literacy beliefs and self-reported practices: On the heels of a new national literacy curriculum. Teaching and Teacher Education, 39. https://doi.org/10.1016/j.tate.2013.12.004.

Tanti, Kurniawan, D. A., Sukarni, W., Erika, \& Hoyi, R. (2021). Description of Students Response Toward the Implementation of Problem-Based Learning Model in Physics Learning. Jurnal Ilmu Pendidikan Fisika, 6(1), 30-38. https://doi.org/10.26737/jipf.v6i1.1787.

Tempola, F., Muhammad, M., \& Mubarak, A. (2020). Penggunaan Internet Dikalangan Siswa SD di Kota Ternate: Suatu Survey, Penerapan Algoritma Clustering dan Validasi DBI. Jurnal Teknologi Informasi Dan Ilmu Komputer, 7(6). https://doi.org/10.25126/jtiik.2020722370.

Tsivitanidou, O. E., \& Constantinos. (2016). A study of students' heuristics and strategy patterns in web-based reciprocal peer assessment for science learning. The Internet and Higher Education, 29. https://doi.org/10.1016/j.iheduc.2015.11.002.

Uygarer, R., \& Uzunboylu, H. (2017). An investigation of the digital teaching book compared to traditional books in distance education of teacher education programs. Eurasia Journal of Mathematics, Science and Technology Education, 13(8), 5365-5377. https://doi.org/10.12973/eurasia.2017.00830a.

Villamil, S., Hernández, C., \& Tarazona, G. (2020). An overview of internet of things. Telkomnika (Telecommunication Computing Electronics and Control), 18(5). https://doi.org/10.12928/TELKOMNIKA.v18i5.15911.

Vrieling, E. M., Bastiaens, T. J., \& Stijnen, S. (2012). Effects of increased self-regulated learning opportunities on student teachers' metacognitive and motivational development. International Journal of Educational Research, 53. https://doi.org/10.1016/j.ijer.2012.03.014.

Widiantini, N. N. A. S., Putra, M., \& Wiarta, I. W. (2017). Model Pembelajaran Sets (Science, Environment, Technology, Society) Berbantuan Virtual Lab Berpengaruh Terhadap Kompetensi Pengetahuan IPA. Journal of Education Technology. https://doi.org/10.23887/jet.v1i2.11776. 
Xiao, Y., \& Yang, M. (2019). Formative assessment and self-regulated learning: How formative assessment supports students' self-regulation in English language learning. System, 81. https://doi.org/10.1016/j.system.2019.01.004.

Yusuf, I., \& Widyaningsih, S. W. (2020). Implementing e-learning-based virtual laboratory media to students' metacognitive skills. International Journal of Emerging Technologies in Learning, 15(5), 63-74. https://doi.org/10.3991/ijet.v15i05.12029.

Zendler, A., \& Greiner, H. (2020). The effect of two instructional methods on learning outcome in chemistry education: The experiment method and computer simulation. Education for Chemical Engineers. https://doi.org/10.1016/j.ece.2019.09.001.

Zhang, Y., Ghandour, A., \& Shestak, V. (2020). Using Learning Analytics to Predict Students Performance in Moodle LMS. International Journal of Emerging Technologies in Learning. https://doi.org/10.3991/ijet.v15i20.15915. 